\title{
MIR516B1 wt Allele
}

National Cancer Institute

\section{Source}

National Cancer Institute. MIR516B1 wt Allele. NCI Thesaurus. Code C82493.

The human MIR516B1 wild-type allele is located in the vicinity of $19 q 13.41$ and is approximately 89 bases in length. This allele, which encodes MIR516B1 pre-miRNA, plays

a role in the regulation of gene expression. Alteration in the expression of this gene is associated with development of breast cancer. 